\title{
Effect of Planting Pattern and Cutting Height on In Vitro Digestibility and in Sacco Degradability of Napier Grass Mixed with Silver Leaf Desmodium at Bako, Western Ethiopia
}

\author{
Diriba Diba $^{1^{*}}$ and Adugna Tolera ${ }^{2}$ \\ ${ }^{1}$ Department of Animal Sciences, College of Agriculture and Natural Sciences, \\ Wollega University Post Box No: 395, Nekemte, Ethiopia \\ ${ }^{2}$ Department of Animal and Range Sciences, College of Agriculture, Hawassa University, \\ Post Box No: 05, Awassa, Ethiopia
}

\begin{tabular}{|c|c|}
\hline \multirow{6}{*}{$\begin{array}{l}\text { Abstract } \\
\text { In vitro digestibility and in sacco dry matter (DM) degradability of Napier grass/silver leaf } \\
\text { Desmodium mixtures were carried out using } 3 \times 2 \text { factorial experiment arranged in } \\
\text { randomized complete block design with three replications. The treatments were three } \\
\text { levels of stubble cutting heights }(20 \mathrm{~cm}, 30 \mathrm{~cm} \text {, and } 40 \mathrm{~cm}) \text { and two levels of planting } \\
\text { patterns (same row and alternate row). For the legume component DM disappearance } \\
\text { after } 24,48,72 \text { and } 96 \text { hours of incubation significantly }(p<0.05) \text { increased with increasing } \\
\text { cutting heights }(20 \mathrm{~cm} \text { to } 40 \mathrm{~cm}) \text { during second year production season. Both factors had no } \\
\text { significant effect on DM disappearance and most of degradability characteristics of the } \\
\text { grass component during first year, however, in vitro DM digestibility was higher }(p<0.05) \\
\text { for alternate than same row planting pattern and increased significantly ( } p<0.01) \text { with } \\
\text { increasing cutting height. During second year, alternate row planting pattern showed } \\
\text { higher ( } p<0.05) \text { DM disappearance after } 48,72 \text { and } 96 \text { hours of incubation. Significant } \\
\text { difference for DM degradation between cutting heights were observed for } 72 \text { and } 96 \text { hours } \\
\text { of incubation. Among degradability characteristics, slowly fermentable fraction significantly } \\
\text { increased }(p<0.05) \text { with increasing cutting height. The in vitro DM digestibility of the } \\
\text { second season harvest of grass followed similar trend of the first harvest grass }\end{array}$} & Article Information \\
\hline & $\begin{array}{l}\text { Article History: } \\
\text { Received : } 09-04-2013 \\
\text { Revised : } 13-06-2013 \\
\text { Accepted : 18-06-2013 }\end{array}$ \\
\hline & Keywords: \\
\hline & $\begin{array}{l}\text { Cutting height } \\
\text { Planting patterns, } \\
\text { Napier grass, } \\
\text { Silver leaf Desmodium, } \\
\text { Bako }\end{array}$ \\
\hline & *Corresponding Author: \\
\hline & \\
\hline
\end{tabular}

\section{INTRODUCTION}

The main sources of livestock feed in subSaharan African countries are natural pasture and crop residues, which are characterized by poor nutritional quality and insufficient and seasonal supply. In such situations reliable and sustainable animal production can hardly be anticipated (Lemma et al., 1991). Such cases encourage the use of high yielding forage crops like Napier grass (Pennisetum purpureum) as it gives high yields from a small plot of land (Tarawali et al., 1995). Its leafy nature, considerable plant height, high tillering, and re-growth potential makes it a highly productive fodder crop per unit area of land as compared to other grass species (Whiteman, 1980; Mwangi, 1994). Because of high cost of synthetic nitrogen fertilizers, pasture improvement based on biological nitrogen fixation will assume increasing importance
(Whiteman, 1980; Mwangi and Wambugu, 2002; Mbuthia and Gachuiri, 2002).

But like other tropical grasses, the issue of nutrient density and availability (digestibility) is a subject of concern in Napier grasses. Forage management practices such as cutting height and spacing affects DM yield and forage quality (ASA, 1976). Nylon bag techniques and in vitro DM digestibility are some of the methods available for evaluating forage quality and or digestibility (Van Soest and Robertson, 1980). Moreover, management practices such as cutting height and spacing that give a satisfactory compromise between the DM yield and digestibility of the grass and/or the mixed stand as a whole needed to be identified. Thus, the objective of this study was to 
Diriba Diba et al.,

determine optimum cutting heights and appropriate planting patterns of Napier grass-sliver leaf Desmodium mixed pasture that optimizes both in vitro digestibility and in sacco degradability of the forages.

\section{MATERIALS AND METHODS \\ Description of the Study Area}

The mixture of Silver leaf Desmodium and Napier grass was established at Bako Agricultural Research Center located in East Wellega Zone of Oromia Regional State, Western Ethiopia at an altitude of 1650 m.a.s.l. Bako is located at $9^{\circ} 6^{\prime} \mathrm{N}$ latitude and $37^{\circ} 09^{\circ} \mathrm{E}$ longitude at a distance of 260 $\mathrm{km}$ west of Addis Ababa.

The area experiences a sub humid tropical climate with unimodal rainfall pattern i.e. one main rainy season. The mean minimum and maximum long-term (45 years) precipitation for the area were $13.1 \mathrm{~mm}$ in January and $253.8 \mathrm{~mm}$ in July, respectively. The major rainy season covers the months from April to October and the maximum fall occurs in July and August with mean value of 253.8 $\mathrm{mm}$ and $232.2 \mathrm{~mm}$, respectively. The total annual rainfall in 2004 and 2005, the years when the experiment was conducted, were $1,161.0 \mathrm{~mm}$ and $1,258.1 \mathrm{~mm}$, respectively.

The mean minimum, mean maximum and average air temperatures of the area recorded for 45 years were $13.3,27.9$ and $20.7^{\circ} \mathrm{C}$, respectively. During the experimental years, 2004 and 2005, the mean minimum, maximum and average monthly air temperatures were, 13.2, 28.7 and $21.0{ }^{\circ} \mathrm{C}$, respectively for the former and 13.5, 29.7 and 21.4 ${ }^{\circ} \mathrm{C}$ for the latter year (unpublished metrological data of Bako Agricultural Research Center). The major farming system of the area is a mixed crop-livestock production system.

\section{Experimental Design and Treatments}

A 3X2 factorial combination arranged in randomized complete block design (RCBD) with three replicates was used in the experiment. The treatments were two levels of planting patterns (same row and alternate row) and three levels of stubble cutting height (20, 30 and 40 above ground).

\section{Forage Management}

Napier grass stem cutting and seeds of silver leaf Desmodium were used for establishment of the mixed pasture, which were managed under rain-fed system. Starter fertilizers of 1:1 ratio DAP to Urea $200 \mathrm{~kg} / \mathrm{ha}$ of each were applied during the establishment year (Chadhokar, 1978) whereas no fertilizer was applied in the second year. The grass with accession number ILRI-14389 was cut into
Sci. Technol. Arts Res. J., April-June 2013, 2(2): $22-29$

pieces constituting three nodes, where two of the nodes were put in well-prepared soil whereas the remaining third node was left above the ground (Skerman and Riveros, 1989). The distance between the plants within a row was $0.5 \mathrm{~m}$ whereas the distance between rows was $0.75 \mathrm{~m}$ (Khan, 2002). The grass component was intercropped with the legume silver leaf Desmodium simultaneously at two different planting patterns. Weeds were controlled by hand pulling especially for the sole silver leaf Desmodium but no weeding was performed in all mixed stand plots because of high dominance of the pasture against weeds. The experiment was executed for two consecutive cropping seasons, 2004 and 2005. In vitro DM digestibility (IVDMD) and in sacco degradability were used to evaluate the nutritive value of the two mixed pasture species grown together.

During harvesting, forage samples were cut manually using sickles. Both the grass and the legume were cut at different heights $(0.20,0.30$ and $0.40 \mathrm{~m}$ ) above the ground when the upper plant height reached $90-120 \mathrm{~cm}$ height ranges (IIRR, 1998; Tessema et al., 2002). Two forage harvests were taken within two cropping seasons as the prolonged dry seasons retarded its growth rates and thereby the frequency of harvesting. The fresh weight $(300 \mathrm{~g})$ of the forage biomass was taken in the field. After chopping the samples were sun dried during the first harvest and then transferred to a known weight paper bags and dried in a forced draft oven at a temperature of $60{ }^{\circ} \mathrm{C}$ for 48 hours and reweighed to determine the partial DM content. The dried samples were ground to pass 1-mm for use in chemical analysis and IVDMD but the 2-mm sieve sizes to be used for determination of in sacco DM degradability of the forages.

\section{In Sacco DM Degradability}

Dry matter degradation of the feeds was determined by incubating about $2.5 \mathrm{~g}$ of the dry samples, ground to pass through $2 \mathrm{~mm}$ sieve, in nylon bags (pore size $40 \mu \mathrm{m}$ ) in three rumen fistulated mature rams of the local sheep from Adilo, southern Ethiopia. During the experiment the animals were fed $450 \mathrm{~g}$ Desmodium intortum (cv. green leaf) hay, 450-g Cynodon dactylon dominated native pasture hay and $100 \mathrm{~g}$ concentrate composed of equal proportion of ground maize and wheat bran. All bags were consistently incubated 1 $\mathrm{h}$ after the sheep were offered feed and withdrawn after 4, 8, 16, 24, 48, 72 and $96 \mathrm{~h}$ of incubation. Immediately after being withdrawn from the rumen, the bags were rinsed with cold water and washed in domestic washing machine for 30 minutes (first for 15-min, then for 10-min and lastly for 5-min) until the rinsing water become clear. The bags were dried in forced draft oven to constant weight at $60^{\circ} \mathrm{C}$ for $48 \mathrm{~h}$ 
Diriba Diba et al.,

and weighed after cooling in a desiccator. Washing losses were determined by soaking two bags per sample in warm tap water $\left(\sim 39{ }^{\circ} \mathrm{C}\right)$ for $1 \mathrm{~h}$ followed by washing and drying as before.

DM degradation data was fitted to the exponential equation $p=a+b\left(1-e^{-c t}\right)$ where $p$ is $D M$ degradation (\%) at time $t$ (Ørscov and McDonald, 1979; McDonald, 1981) using the Neway Excel Programme (Chen, 1995). Since the washing loss (A) was higher than the estimated rapidly soluble fraction (a), the lag time was estimated by fitting the model $p=\mathrm{A}$ for $\mathrm{t} \leq \mathrm{t}_{0}, p=\mathrm{a}+\mathrm{b}\left(1-\mathrm{e}^{\mathrm{ct}}\right)$ for $\mathrm{t}>\mathrm{t}_{\mathrm{o}}$ and the degradation characteristics of the forage mixtures were defined as $A=$ washing loss (rapidly soluble fraction); $B=(a+b)-A$, which is the insoluble but fermentable part; $c=$ the fractional rate constant at which $B$ will be degraded and the lag phase $(L)$ $=1 / \log _{\mathrm{e}}[\mathrm{b} /(a+b-A)]$. The effective DM degradability of the forage species was calculated at rumen outflow rate of $0.05 \mathrm{~h}^{-1}$.

\section{Statistical Analysis}

Analysis of variance was carried out on the in vitro DM digestibility and in sacco DM degradability data using the General Linear Model Procedure of the Statistical Analysis System (SAS) computer software (SAS, 2003). Mean comparison was done using the least significance difference (LSD).

\section{RESULTS AND DISCUSSION}

In this result and discussion part, each of the legume and grass components were separately treated even though they were grown together as a mixed pasture. This was happened for three main reasons: first if the mixed components (Napier grass and Silver leaf Desmodium) were mown together and analyzed together, the nutritive value obtained during first year inevitably varies from what is expected in the second year due to dynamic agronomic progress of the two components and hence the recommendation may not, later on, apply for Napier Desmodium mixed pasture grown elsewhere. Secondly, if the herbages are cut together and analyzed together, it brings difficulty to separately calculate the amount of nitrogen fixed by
Sci. Technol. Arts Res. J., April-June 2013, 2(2): $22-29$

the legume and supplied to the grass through its root in mixed stand since it can be confused with the nitrogen coming from the leaves of the legume to the total mixture. Thirdly, the different nutrients contained in separate components (Napier and Silverleaf Desmodium) are more constant than the composition of their mixture (depends on the relative proportion of the components) and is more important in feedlot ration formulation

\section{The Legume Component}

Effect of Planting Patterns and Cutting Heights on Nylon Bag DM Degradability of Silver Leaf Desmodium during First Year Harvest

Effect of planting patterns and cutting heights on in sacco DM degradability of silver leaf Desmodium is given in Table 1. Non-significantly higher DM degradation was noted for alternate row than same row planting patterns in all incubation periods. However, more visible differences occurred between times of incubation than planting strips. Cutting height also non-significantly influenced DM degradability throughout the incubation periods. Increase in cutting height from 20 to $40 \mathrm{~cm}$ resulted in consistent increase of DM degradability for all incubation times with the exception of 4 hours of incubation in which no clear trend was noted.

The DM degradability characteristics were not significantly affected $(p>0.05)$ both by planting pattern and by cutting height. However, the degradation rate and the effective degradability tended to be higher, while the lag was lower in alternate row planting than same row planting approach. Similarly, the degradation rate and effective degradability tended to increase while the lag time tended to decrease with increased cutting stubble height. Alternate row planted legume resulted in relatively higher in vitro DM digestibility than same row and increased cutting height resulted in increased $(p>0.05)$ digestibility. Figures 1 and 2 below for both first and second year harvests of Silver leaf Desmodium indicated that further and significant $(p<0.05)$ DM degradation did not occur after 70 hours of incubation.

Table 1: Effect of planting patterns and cutting heights on in sacco DM degradability of silver leaf Desmodium at first harvest.

\begin{tabular}{|c|c|c|c|c|c|c|c|}
\hline \multirow{2}{*}{ Degradability characteristics } & \multicolumn{2}{|c|}{ Planting patterns } & \multicolumn{4}{|c|}{ Cutting heights } & \multirow[b]{2}{*}{ SEM } \\
\hline & Within row & Alternate row & SE & $20 \mathrm{~cm}$ & $30 \mathrm{~cm}$ & $40 \mathrm{~cm}$ & \\
\hline \multicolumn{8}{|l|}{ In vitro DM digestibility } \\
\hline $72 \mathrm{~h}$ in sacco degradability: & 52.3 & 54.2 & 1.9 & 49.7 & 52.3 & 55.2 & 2.3 \\
\hline Washing loss $(A)$ & 23.3 & 23.5 & 0.00 & 23.1 & 23.2 & 23.8 & 0.00 \\
\hline Slowly fermentable fraction (B) & 45.3 & 46.3 & 1.20 & 44.6 & 46.0 & 46.7 & 1.5 \\
\hline Potential degradability (PD) & 69.6 & 68.8 & 1.2 & 68.5 & 69.3 & 69.9 & 1.5 \\
\hline Degradation rate $(\mathrm{c})$ & 0.04 & 0.05 & 0.01 & 0.04 & 0.04 & 0.05 & 0.001 \\
\hline Lag time & 1.4 & 1.0 & 0.47 & 1.9 & 0.98 & 0.70 & 0.58 \\
\hline Effective degradability (ED) & 42.2 & 44.6 & 1.4 & 41.5 & 43.5 & 45.2 & 1.7 \\
\hline
\end{tabular}


Diriba Diba et al.,

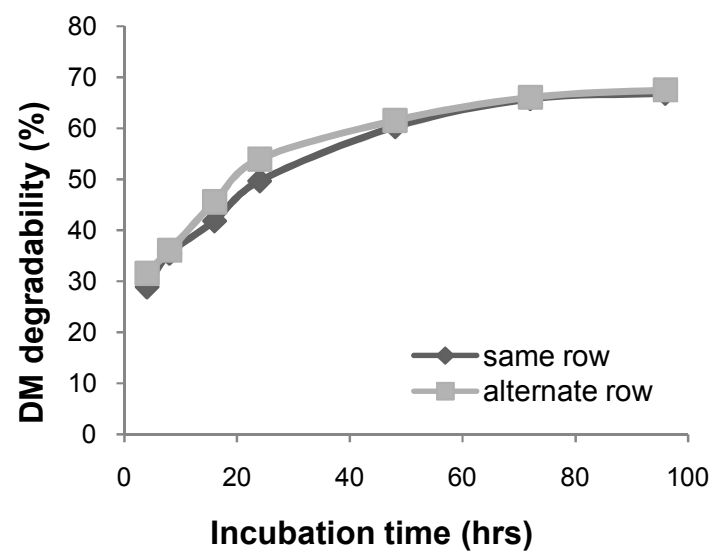

Figure 1: Effect of planting patterns on silver leaf Desmodium rumen degradability $\left(1^{\text {st }}\right.$ harvest).

Effect of Planting Patterns and Cutting Heights on Nylon Bag Dm Degradability of Silver Leaf Desmodium during Second Harvest

Effect of planting patterns and cutting heights on nylon bag DM degradability of silver leaf Desmodium harvested during second year is indicated in Table 2. There is no significant difference between planting strips for all time of incubation and degradability characteristics. However, relatively better DM degradability is noted in alternate than same row for incubation periods. Though not significantly differed $(p<0.05)$, the same row planting patterns gave higher values of degradability characteristics except for degradation rate and effective degradability. The former had equal values in both patterns of planting while the latter was higher in alternate than same row strips.
Sci. Technol. Arts Res. J., April-June 2013, 2(2): 22-29

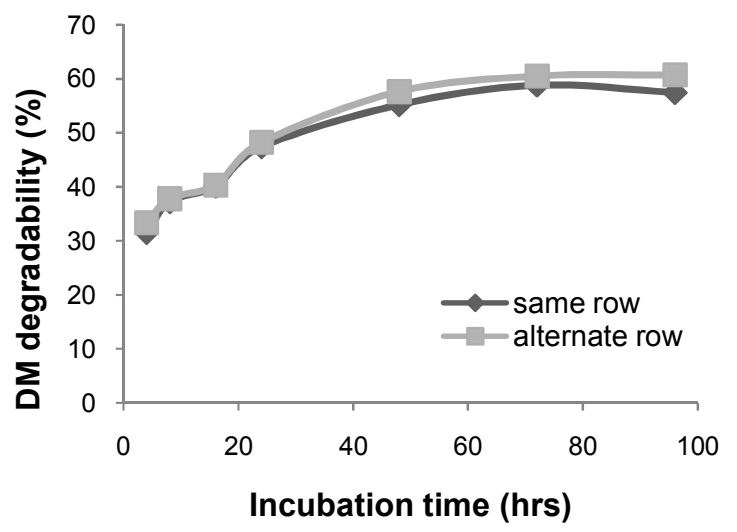

Figure 2: Effect of planting patterns on silver leaf Desmodium rumen degradability $\left(2^{\text {nd }}\right.$ harvest).

The DM disappearance from the nylon bag after 24 hours of incubation was significantly higher $(p<0.05)$ at a cutting height of $40 \mathrm{~cm}$ than the two lower cutting heights (Figure 3 and 4). Similarly, the DM disappearance after 48 and 72 hours of incubation and the PD were significantly higher $(p<0.05)$ at cutting height of 40 and $30 \mathrm{~cm}$ than at $20 \mathrm{~cm}$ cutting height. The DM disappearance after 96 hours of incubation, the slowly degradable fraction and the effective degradability were significantly higher $(p<0.05)$ at a cutting height of 40 $\mathrm{cm}$. Figures 3 and 4 below indicates the diagrammatic presentation of the effects of stubble cutting heights on DM degradability of the legume during both first and second year harvests.

Table 2: Effect of planting patterns and cutting heights on nylon bag DM degradability of silver leaf Desmodium of second harvest.

\begin{tabular}{lccccccc}
\hline \multirow{2}{*}{ Degradability characteristics } & \multicolumn{3}{c}{ Planting patterns } & \multicolumn{4}{c}{ Cutting heights } \\
\cline { 2 - 8 } & Within row & Alternate row & SE & $\mathbf{2 0} \mathbf{~ c m}$ & $\mathbf{3 0} \mathbf{~ c m}$ & $\mathbf{4 0} \mathbf{~ c m}$ & SEM \\
\hline In vitro DM digestibility & 52.5 & 55.1 & 2.1 & 49.9 & 51.2 & 55.3 & 2.5 \\
72 h in sacco degradability: & & & & & & & \\
Washing loss (A) & 21.2 & 22.4 & 0.0 & 21.2 & 21.5 & 22.7 & 0.00 \\
Slowly fermentable fraction (B) & 38.8 & 41.8 & 1.4 & $36.4^{\mathrm{b}}$ & $41.6^{\mathrm{ab}}$ & $42.9^{\mathrm{a}}$ & 1.7 \\
Potential degradability (PD) & 61.2 & 62.9 & 1.4 & $57.9^{\mathrm{b}}$ & $64.1^{\mathrm{a}}$ & $64.4^{\mathrm{a}}$ & 1.7 \\
Degradation rate (c) & 0.04 & 0.04 & 0.04 & 0.03 & 0.04 & 0.04 & 0.005 \\
Lag time & 0.28 & 0.00 & 0.20 & 0.00 & 0.00 & 0.42 & 0.24 \\
Effective degradability (ED) & 41.9 & 41.9 & 0.98 & $40.1^{\mathrm{b}}$ & $41.3^{\text {ab }}$ & $44.3^{\mathrm{a}}$ & 1.2 \\
\hline Means with different letters in a row, considered separately for planting pattern and cutting height, are significantly \\
different
\end{tabular}


Diriba Diba et al.,

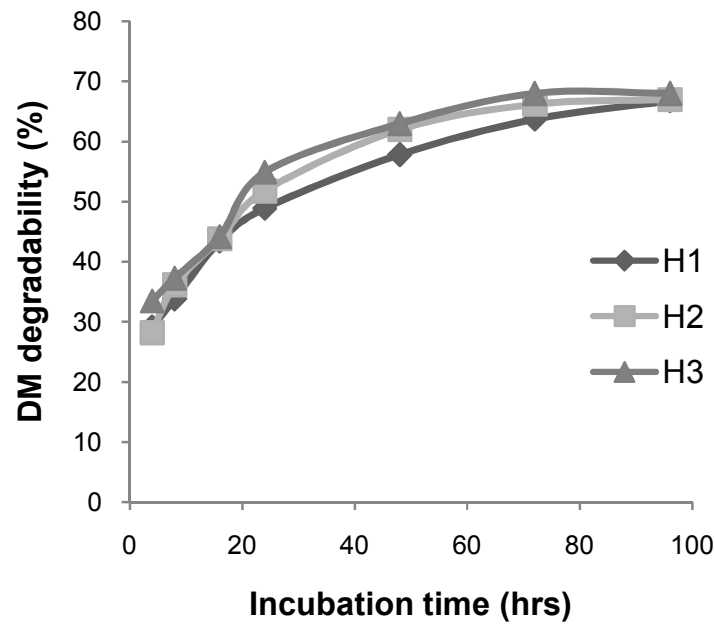

Figure 3: Effect of cutting stubble height on silver leaf Desmodium rumen degradability ( $1^{\text {st }}$ harvest).

\section{Grass Component}

Effect of cutting height and planting patterns on nylon bag DM degradability of the grass component during first harvest

The effect of planting patterns and cutting heights on nylon bag DM degradability after $4,8,16$, $24,48,72$ and 96 hours of incubation and degradability characteristics of the mixed component Napier grass is shown in Figure 5 and 6. The statistical analysis showed that there was no significant difference between the alternate and same row planting patterns for all time of degradation considered. However, except for 72 and 96 hours of degradation, the grass planted in alternate row planting strip tended to show higher degradability than those in the same row with the legume. This may be due to better performance and nodulation of the legume and more supply of $\mathrm{N}$ to the grass in alternate row than within the same rows (Sujatha et al., 1986). The cutting height also resulted in non-significant difference in forage Napier degradability at all times of incubation. Increase in cutting height tended to increase the degradation of the Napier grass at 8, 16, 24, 48, 72, and 96 hours of rumen incubation.
Sci. Technol. Arts Res. J., April-June 2013, 2(2): 22-29

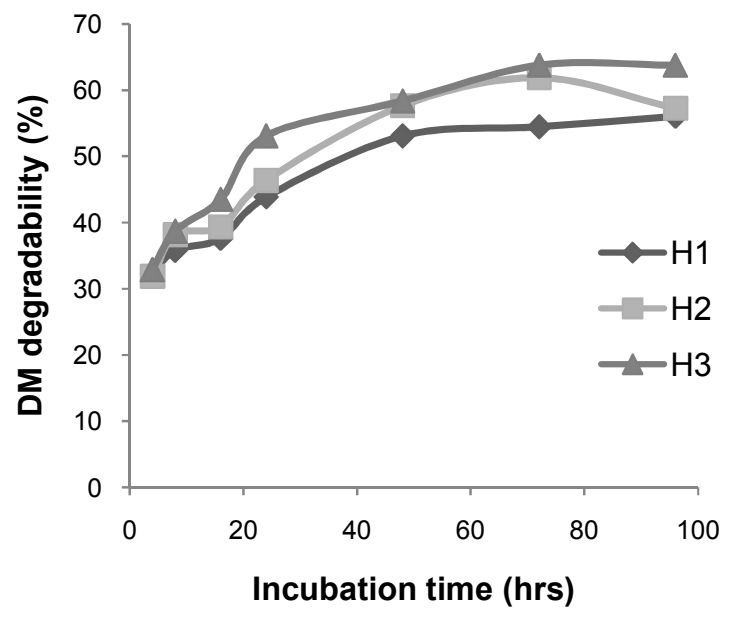

Figure 4: Effect of cutting stubble height on silver leaf Desmodium rumen degradability (second harvest).

On the other hand, washing loss, slowly fermentable fraction, potential degradability, lag time and effective degradability were not significantly different unlike the rate of degradation of gradually fermentable fraction (c) with planting systems. Except for lag phase and effective degradability, all the other degradability characteristics were better in alternate pattern than the same row with silver leaf Desmodium. Decrease in stubble cutting height tended to decrease $(p>0.05)$ the rapidly soluble fraction (A), degradation rate (c), potential degradability (PD) and effective degradability (ED). The gradually fermentable fraction followed the opposite trend whereas there was no consistent trend observed for lag phase. In vitro DM digestibility was significantly $(p<0.05)$ higher for alternate row planted Napier than same row. Increased cutting height from $20 \mathrm{~cm}$ to $40 \mathrm{~cm}$ significantly $(p<0.01)$ increased DM digestibility. Generally, successful degradation results were obtained for both same and alternate row planted grass at both first and second year harvests (Figure 5 and 6).

Table 3: Effect of planting patterns \& cutting heights on nylon bag DM degradability of Napier grass during $1^{\text {st }}$ year.

\begin{tabular}{|c|c|c|c|c|c|c|c|}
\hline \multirow{2}{*}{ Degradability characteristics } & \multicolumn{3}{|c|}{ Planting patterns } & \multicolumn{4}{|c|}{ Cutting heights } \\
\hline & Within row & Alternate row & SE & $20 \mathrm{~cm}$ & $30 \mathrm{~cm}$ & $40 \mathrm{~cm}$ & SEM \\
\hline $\begin{array}{l}\text { In vitro DM digestibility } \\
72 \mathrm{~h} \text { in sacco degradability: }\end{array}$ & $53.4^{D}$ & $61.5^{a}$ & 0.42 & $55.1^{\mathrm{C}}$ & $57.1 \mathrm{~b}$ & $60.4^{\mathrm{a}}$ & 0.52 \\
\hline Washing loss $(A)$ & 22.5 & 23.0 & 0.00 & 21.9 & 22.1 & 24.3 & 0.00 \\
\hline Slowly fermentable fraction (B) & 49.9 & 52.9 & 1.8 & 47.9 & 51.7 & 54.6 & 2.2 \\
\hline Potential degradability (PD) & 72.4 & 75.9 & 1.8 & 72.3 & 73.8 & 76.5 & 2.2 \\
\hline Degradation rate $(c)$ & $0.02^{b}$ & $0.03^{\mathrm{a}}$ & 0.02 & 0.03 & 0.03 & 0.03 & 0.002 \\
\hline Lag time & 2.0 & 1.5 & 0.32 & 2.2 & 1.3 & 1.7 & 0.39 \\
\hline Effective degradability (ED) & 39.9 & 38.7 & 0.51 & 39.0 & 39.2 & 39.6 & 0.62 \\
\hline
\end{tabular}


Diriba Diba et al.,

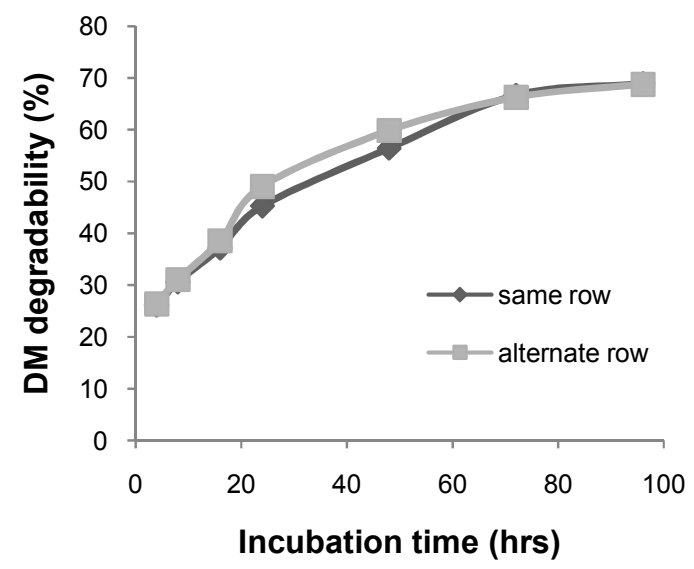

Figure 5: Effect of planting patterns on Napier grass rumen degradability ( $1^{\text {st }}$ harvest).

Effect of cutting height and planting patterns on nylon bag DM degradability of Napier grass mixed components during second harvest

The effect of planting patterns and cutting heights on in saco DM degradability after 4, 8, 16, $24,48,72$, and 96 hours of incubation and degradability characteristics of the mixed component Napier grass was indicated in Figures 7 and 8 . There was no significant difference between the alternate and same row planting patterns for 4 , 8,16 , and 24 hours of incubation. However, for 48 , and 72 hours of degradation, the grass planted in alternate row planting strips had significantly higher $(p<0.05)$ degradability than those in the same row with the legume while the contrary was true at 96 hours of incubation. The degradability of Napier grass tended to increase with increasing cutting height and this is in agreement with the reports of Redfearn et al (1999), and Reeves and Kellaway (1996). At 72 and 96 hours of degradation, an

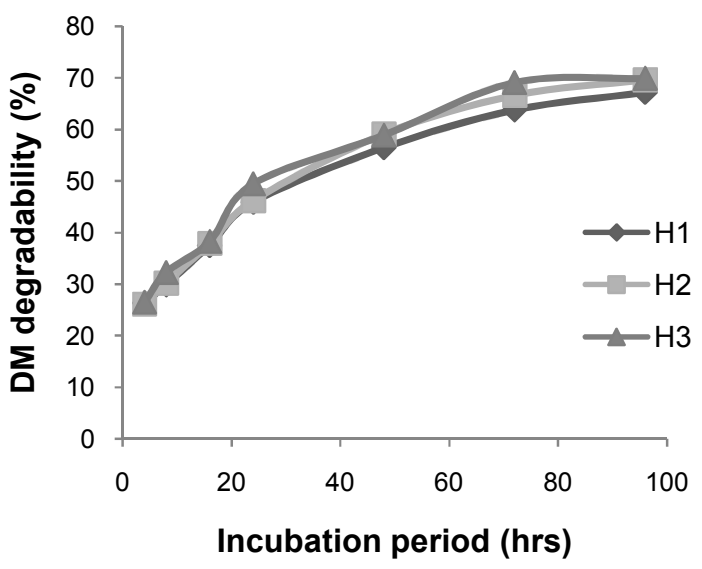

Figure 7: Effect of cutting stubble height on Napier grass rumen degradability ( $1^{\text {st }}$ harvest $)$.
Sci. Technol. Arts Res. J., April-June 2013, 2(2): 22-29

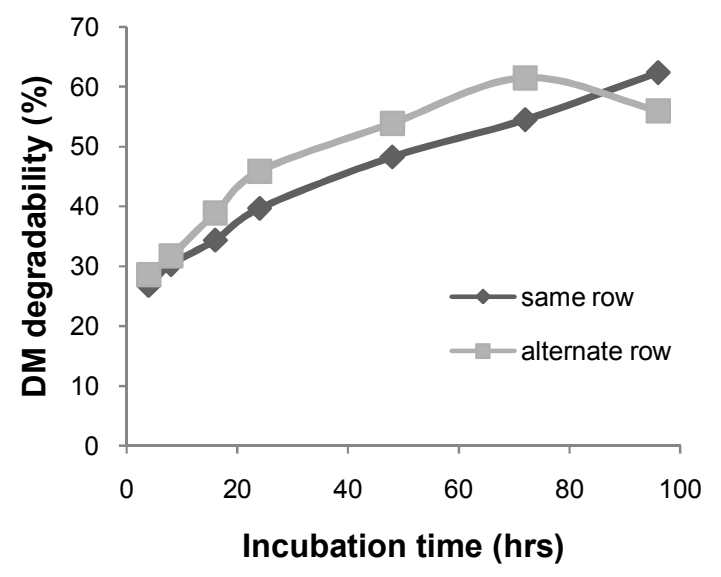

Figure 6: Effect of planting patterns on Napier grass rumen degradability $\left(2^{\text {nd }}\right.$ harvest).

increase in cutting height significantly $(p<0.01)$ increased DM degradability.

Despite the lack of significant variation $(p>0.05)$ observed among all the degradability characteristics for planting patterns, the alternate row planted grass achieved higher values except the lag time. The washing loss $(A)$ increased when the cutting height increased whereas the insoluble, but gradually fermentable fraction (B) significantly $(p<0.05)$ increased with increase in cutting height. The lower cutting height $(20 \mathrm{~cm})$ had medium PD values with the highest for the $30 \mathrm{~cm}$ cutting height. The rate of degradation (c) showed a decreasing trend with direct relation with the cutting height in similar manner as ED. However, the lag time for $30 \mathrm{~cm}$ cutting height was the highest followed by equal values of 20 and $40 \mathrm{~cm}$. The in vitro DM digestibility of the second harvest grass component for planting strips and cutting height followed similar trend of the $1^{\text {st }}$ harvest.

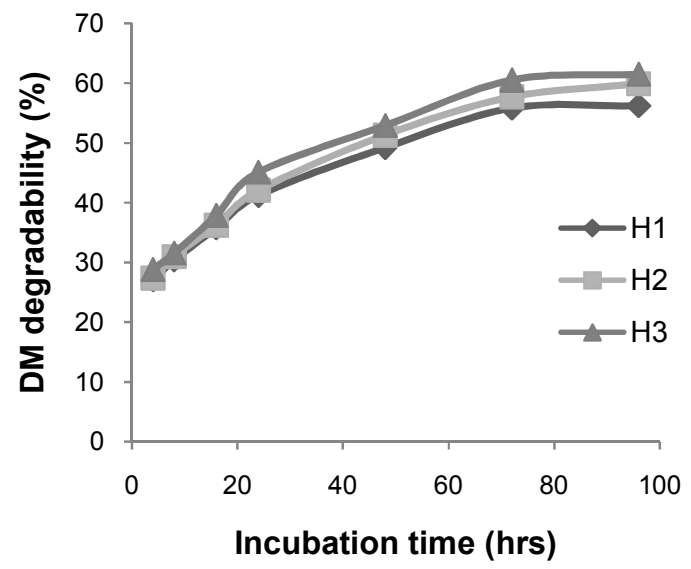

Figure 8: Effect of cutting stubble height on Napier grass rumen degradability ( $2^{\text {nd }}$ harvest). 
Table 4: Effect of planting patterns and cutting heights on nylon bag DM degradability of Napier grass during second year

\begin{tabular}{lccccccc}
\hline \multirow{2}{*}{ Degradability characteristics } & \multicolumn{3}{c}{ Planting patterns } & \multicolumn{4}{c}{ Cutting heights } \\
\cline { 2 - 8 } & $\begin{array}{c}\text { Within } \\
\text { row }\end{array}$ & $\begin{array}{c}\text { Alternate } \\
\text { row }\end{array}$ & SE & $\mathbf{2 0} \mathbf{~ c m}$ & $\mathbf{3 0} \mathbf{~ c m}$ & $\mathbf{4 0} \mathbf{~ c m}$ & SEM \\
\hline In vitro DM digestibility & $54.4^{\mathrm{b}}$ & $62.3^{\mathrm{a}}$ & 0.44 & $56.0^{\mathrm{c}}$ & $58.1^{\mathrm{b}}$ & $60.8^{\mathrm{a}}$ & 0.54 \\
72h In sacco degradability: & & & & & & & \\
Washing loss (A) & 19.7 & 20.7 & 0.00 & 19.5 & 19.8 & 21.4 & 0.00 \\
Slowly fermentable fraction (B) & 43.5 & 45.8 & 2.3 & $37.8^{\mathrm{b}}$ & $45.6^{\mathrm{ab}}$ & $50.6^{\mathrm{a}}$ & 2.83 \\
Potential degradability (PD) & 63.2 & 66.5 & 2.3 & $59.2^{\mathrm{b}}$ & $65.1^{\mathrm{ab}}$ & $70.4^{\mathrm{a}}$ & 2.8 \\
Degradation rate (c) & 0.04 & 0.03 & 0.01 & 0.02 & 0.03 & 0.032 & 0.004 \\
Lag time & 0.03 & 0.00 & 0.02 & 0.00 & 0.05 & 0.00 & 0.03 \\
Effective degradability (ED) & 35.3 & 39.1 & 0.68 & 36.4 & 37.5 & 37.6 & 0.83 \\
\hline
\end{tabular}

Means with different letters in a row, considered separately for planting pattern and cutting height, are significantly different

\section{CONCLUSION}

In the present study in vitro DM digestibility was higher for alternate row planting patterns than same row for both grass and legume and highest for $40 \mathrm{~cm}$ grass stubble cutting height. For In situ rumen degradability of the grass component 72 hours of incubation was found to be optimum period. Planting Napier grass and Silver leaf Desmodium in alternate rows pattern and cutting at $40 \mathrm{~cm}$ stubble heights given higher slowly fermentable fraction, potential degradability and effective degradability of the dry matter for both components in both seasons. Further study is necessary to see the effect of the two mixtures on animal performance.

\section{REFERENCE}

AOAC. (1990). Moisture in peat. In: Official method of analysis of the Association of Official Analytical Chemists. $15^{\text {th }}$ editions, A.O.A.C, Arlington, Virginia. P137.

ASA, (1976). Multiple cropping. American Society of Agronomy 27: 224-226.

Chadhokar, P.A. (1978). Effect of rate and frequency of nitrogen application on DM yield and nitrogen concentration of para grass (Brachiaria mutica). Trop. Grassl. 12: 127-132.

Chen, X.B. (1995). Neway Excel: An Excel Application Program for Processing Feed Degradability Data. International Feed Resources Unit, Rowett Research Institute.

IIRR. (1998). Sustainable agriculture extension manual for eastern and southern Africa. International Institute of Rural Reconstruction. Nairobi, Kenya.

Khan, Z. R. (2002). Push-Pull technology for the poor African farmer: Improving Livelihood of resource poor farmers. International Centers for insect Physiology and ecology, (MPRTC). Mbita, Kenya.
Lemma Gizachew, Alemu Tadesse and Liyusew Ayalew. (1991). Evaluation of different grass-legume mixtures in the mid-altitude sub humid zone of Ethiopia. Ethiopian Society of Animal Production (ESAP) third annual conference, Addis Ababa, Ethiopia.

Mbuthia, E.W. and Gachuiri, C.K. (2002). Effect of inclusion of high protein forage legumes and molasses in Napier grasssilage: silage quality and voluntary DM intake by sheep. LRNP news letter. Kenya Agricultural research Institute, Nairobi, Kenya.

McDonald, I. (1981). A revised model for the estimation of protein degradability in the rumen. Journal of Agricultural Science 96:251-257

Mwangi, D.M. (1994). Survey on feeds, feeding and livestock management in central Kenya. In: proceedings of the $2^{\text {nd }}$ KARI scientific conference. KARI (Kenya Agricultural research Institute), Nairobi, Kenya.

Mwangi, D.M. and Wambugu, C. (2002). Forage legume technologies: Participatory experiences with farmers and community-based organisations in Central Kenya. In: Rangnekar D. and Thorpe W. (eds). 2002. Smallholder dairy production and marketingOpportunities and constraints. Proceedings of a South-South workshop held at NDDB, Anand, India, 13-16 March 2001. NDDB (National Dairy Development Board), Anand, India, and ILRI (International Livestock Research Institute), Nairobi, Kenya.

Ørscov, E.R. and McDonald, I. (1979). The estimation of protein degradability in the Rumen from incubation measurements weighed according to the rate of assage. Journal of Agricultural Science (Cambridge) 92: 499.

Redfearn, D.D., Moore, K.J., Vogel, K.P., Waller, S.S. and Mitchell. R.B. (1999). Fiber digestion dynamics of sward components within swtchgrass populations. Crop Science 39: 784-789. 


\section{Diriba Diba et al.,}

Reeves, M., Fulkerson, W.J. and Kellaway, R.C. (1996). Forage quality of Kikuyu (Pennisetum clandestinum): The effect of time of defoliation and nitrogen fertilizer application and in comparison with perennial ryegrass (Lolium perene). Australian Journal of Agricultural Research 47:1349-1359.

SAS. (2003). Guide to personal computers. Version 9.1.3.: Statistical Analysis System (SAS) Institute Inc., Cary, NC.

Skerman, P.J. and Riveros, F. (1989). Tropical grasses. Food and Agricultural Organization of the United Nations, Rome Italy.

Sujatha, P., Allen, V.G., Fontenot, J.P and McClure, W.H. (1986). Yield, chemical composition and digestibility by sheep of orchard grass fertilized with different rates of Nitrogen and Sulphur or associated red clover. Journal of Animal Science 62: 813-821.

Tarawali S.A., Tarawali G., Larbi, A. and Hanson, J. (1995). Method for evaluation oflegumes, grasses and fodder trees for use as livestock feed. ILRI manual 1.
Sci. Technol. Arts Res. J., April-June 2013, 2(2): 22-29

ILRI (International Livestock Research Institute), Nairobi, Kenya.

Tessema Zewudu., Baars, R.M.T and Alemu Yami. (2002). Effect of plant height at cutting, source and fertilizer level on yield and nutritional quality of Napier grass (Napier grass (L.) Schumach). African Journal of Range \&Forage science South Africa.

Tolera A., Sundstøl, F. and Said, A.N. (1998). The effect of stage of maturity on yield and quality of maize and stover. Animal Feed Science and Technology 75:157168.

Van Soest, P.J., and Robertson, J.B. (1980). System of analysis for fibrous feeds. In:"standardization of analytical methodology for feeds". Proceedings of a workshop at International Development Research Center (IDRC), 1979. (Eds WJ Pidgen, C.C. Balch, M. Graham). PP 49-60 (IDRC:Ottawa).

Whiteman P.C. (1980). Tropical Pasture Science. Oxford University Press. New York, U.S.A. 